\title{
Characteristics of corneal donations in state of Piauí
}

\section{Características das doações de córnea no estado do Piauí}

\author{
Namir Clementino Santos ${ }^{1}$, Virgínia Lúcia Bezerra², Eduardo Carvalho de Melo²
}

\begin{abstract}
Objective: To describe the profile of corneal donations obtained by Ocular Tissue Bank, Hospital Getúlio Vargas (BTOC-HGV), assess the quality of the captured tissue and list the indications for corneal transplant. Methods: Retrospective study of registered donors in BTOC-HGV in the period 2008-2011. Collected data were: age, gender and cause of death of the donor, enucleation time, preservation time, quality of the donated cornea, causes of discards and indications for penetrating keratoplasty in BTOC. Results: Were analyzed 311 records of donor cornea BTOC-HGV. The number of donations increased from 9 in 2008 to 80 in 2009 , 109 in 2010 and 113 in 2011. Most donors were male. The average age of the donors was $43.00 \pm 16.01$ years. The majority of transplanted corneas $(78.6 \%)$ was optics. Were discarded $7.16 \%$ of corneal optics, mostly by new tectonic classification and detection of positive serology. The time of enucleation was $3.77 \pm 2.18$ hours and preservation was $6.86 \pm 6.10$ hours. The most frequent causes of death were external causes, followed by diseases of the circulatory, respiratory, digestive and genitourinary systems. The main indication for transplantation was bullous keratopathy, followed by keratoconus and corneal perforation. Conclusion: This study demonstrated the existence of factors associated with quality of corneas by BTOC as age, time between enucleation and preservation and cause of death. The main indication for transplantation was bullous keratopathy.
\end{abstract}

Keywords: Corneal transplantation, donor tissue; tissue preservation; Eyes bank; Bullous keratopathy

\section{ReSUMO}

Objetivo: Traçar o perfil das doações de córnea obtidas pelo Banco de Tecidos Oculares do Hospital Getúlio Vargas (BTOC-HGV), avaliar a qualidade do tecido captado e enumerar as indicações do transplante de córnea. Métodos: Estudo retrospectivo de ficha de doadores cadastrados no BTOC-HGV no período de 2008 a 2011. Foram coletados dados de idade, gênero e causa do óbito do doador, tempo de enucleação, tempo de preservação, qualidade da córnea doada, causas de descartes e indicações de transplante de córnea no BTOC. Resultados: Foram analisadas 311 fichas de doadores de córnea do BTOC-HGV. O número de doações aumentou de 9 em 2008 para 80 em 2009, 109 em 2010 e 113 em 2011. A maioria dos doadores era do gênero masculino. A média da idade dos doadores foi de 43,00 \pm 16,01 anos. A maioria das córneas transplantadas (78,6\%) foi óptica. Foram descartadas 7,16\% das córneas ópticas, sendo a maioria por nova classificação em tectônica e detecção de sorologia positiva. O tempo de enucleação foi de $3,77 \pm$ 2,18 horas e o de preservação foi de 6,86 $\pm 6,10$ horas. A causa mortis mais frequente foram causas externas, seguida por doenças do aparelho circulatório, respiratório, digestivo e geniturinário. A principal indicação de transplante foi ceratopatia bolhosa, seguida por ceratocone e perfuração corneana. Conclusão: Este estudo demonstrou a existência de fatores associados à qualidade das córneas captadas pelo BTOC como idade, tempo entre a enucleação e a preservação e causa do óbito. A principal indicação de transplante foi ceratopatia bolhosa.

Descritores: Transplante de córnea; Doadores de tecidos; Preservação de tecido; Banco de olhos; Ceratopatia bolhosa

${ }^{1}$ State University of Piauí.Teresina/PI, Brazil; Federal University of Piauí,Teresina/Pl, Brazil.
${ }^{2}$ Federal University of Piauí.Teresina/PI, Brazil.

Getúlio Vargas Hospital, Teresina, Piauí, Brazil

Os autores declaram não haver conflitos de interesse.

Recebido para publicação em 31/12/2013 - Aceito para publicação em 28/8/2014

Rev Bras Oftalmol. 2014; 73 (6): 351-7 


\section{INTRODUCTION}

$\mathbf{C}$ orneal diseases, the second leading cause of reversible blindness worldwide, generally affect the young and economically active population, causing a significant economic and social burden ${ }^{1}$.Corneal transplantation is the most successful transplant procedurebetween humans and is among the most frequently performed worldwide.However, the quality of donated corneas and proper conservation until transplantation are critical to the success of the procedure and for a good visual prognosis.

The prevalence of corneal diseases varies between countries and regions, depending on public health and socio-economic conditions $^{2,3}$. In the US, the most common indication for corneal transplantation is bullous keratopathy, while in Europe and Brazil studies report keratoconus as the main indication, although there are variations between different regions within these countries $^{2}$.

Evaluating the cornea in an eye bank is important for ensuring its quality and to minimise postoperative complications.Studies have found that donor age, the time between death and enucleation, and the time between enucleation and preservation are factors related to the morphological quality of corneas in eye banks.

Other relevant studies show that the level of knowledge and understanding of the individual patient about the procedure are as important to the success of treatment as the surgical technique itself.The lack of information about the procedure and about the limitations in visual recovery can produce false expectationscausing patients to neglect the postoperative follow-up, which could compromise the surgical outcome and generate dissatisfaction ${ }^{4}$.

Despite the efforts that have been made in recent years by eye banks and search teams, the number of corneas donated for transplantation in Brazil is still insufficient.Eye Banksare responsible forharvesting, processing, evaluating, classifying, storing, and distributing ocular tissues, and their establishment and operationare subject to legal requirements ${ }^{5}$. This paper will present the results of the first survey on the eye bank of Getulio Vargas Hospital in Teresina/PI, from its inauguration in May 2007until2011. This was a self-assessmentstudy aimed at identifying shortcomingsin our harvesting process that may need to be improved.

This study aimed to determine the profile of corneas donated to the Eye Tissue Bank of Getulio Vargas Hospital (BTOCHGV) from 2008to 2011, performing a quantitative and qualitative evaluation of harvested tissues based on the following parameters:age, gender, and cause of death of the donor;assessment of the cornea by an expert; main reasons for tissue discard;and the timesbetween death and enucleation and between enucleation and preservation. The study also assessed the main indications for corneal transplantation during the study period.

\section{MethodS}

The records of 311 corneal donations to the Eye Tissue Bank (BTOC) of Getúlio Vargas Hospital (HGV) between January 2008 and December 2011 were reviewed.Data were obtained from BTOC-HGVrecordscontainingofficial information on the corneas harvested during the study period.Collected data included age, gender, cause of donor death according to the International Classification of Diseases (ICD-10), time between death and enucleation of the eye globe (enucleation time), and time between enucleation and preservation of corneal tissue (preservation time).The quality of donated corneas (based on slit lamp examination), the number of discarded corneas, the causes of disposal, and the main indications for corneal transplantation based on surgical reports delivered to BTOC were also assessed.Enucleation of eye globes and corneal preservation were performed by trained ophthalmologists.

At BTOC-HGV, corneas and eye globes are assessed by corneal specialiststhrough slit lamp biomicroscopy immediately before inclusion in apreservation medium (Optisol GS ${ }^{\mathrm{TM}}$, BauschLomb), 24 hours after preservation, and every 48 hours after the initial assessmentuntil they are used.In total, 13 different aspects of corneal morphology are assessed and graded from 0 to 4:epithelial exposure, epithelial defect, subepithelial opacity, stromal oedema, stromal folds, stromal infiltrate, Descemet's membrane folds, loss of endothelial cells, cornea guttata, senile arc, pterygium, scars, and specular reflection. Examination is based on Standard Operating Procedure BTOC 012 from its Technical Operations Manual (Figure 1).Depending on the results of examination, corneas are then classified as excellent, good, fair, poor, or unacceptable.

Corneas classified as grade 4 in any item are considered unacceptable by the Eye Bank.

Corneas classified as grade 3 (poor) in one or more items should be distributed with caution and are usually reserved for emergency situations (tectonic transplant).

Surgeons must be warned about corneas classified as grade 2 (fair) or worse in any of the items.

Donated corneas classified as grade 0 (excellent) or 1 (good) are accepted for distribution are used for optical transplants.

Corneas with stromal infiltrates are discarded.

Patients whose forms were incomplete were excluded from the study; these included two forms lacking information on corneal quality, six on the recipient's diagnosis, five on the time between donation and enucleation, and ten on the time between enucleation and preservation. The missing items in these forms were not included in the study results.

\begin{tabular}{|c|c|c|c|c|c|c|}
\hline \multicolumn{2}{|c|}{ Right eye } & \multicolumn{5}{|c|}{ Left eye } \\
\hline $\begin{array}{lllll}0 & 1 & 2 & 3 & 4\end{array}$ & Epithelial exposure & 0 & 1 & 2 & 3 & \\
\hline 01234 & Epithelial defect & 0 & 1 & 2 & 3 & \\
\hline 01234 & Subepithelial opacity & 0 & & 2 & 3 & \\
\hline 01234 & Stromal oedema & 0 & 1 & 2 & 3 & \\
\hline 01234 & Stromal folds & 0 & 1 & 2 & 3 & \\
\hline 01234 & Stromal infiltrate & 0 & 1 & 2 & 3 & \\
\hline 011234 & Descemet's membrane folds & 0 & 1 & 2 & 3 & \\
\hline 012334 & Loss of endothelial cells & 0 & 1 & 2 & 3 & \\
\hline 01234 & Cornea guttata & 0 & 1 & 2 & 3 & \\
\hline 01234 & Senile arc & 0 & 1 & 2 & 3 & \\
\hline 012334 & Pterygium & 0 & 1 & 2 & 3 & \\
\hline 012334 & Scars & 0 & 1 & 2 & 3 & \\
\hline 012334 & Specular reflection & 0 & 1 & 2 & 3 & \\
\hline
\end{tabular}

Figura 1: Modelo da ficha utilizada no Banco de Tecidos Oculares do Hospital Getúlio Vargas para avaliação da córnea doada na lâmpada de fenda 


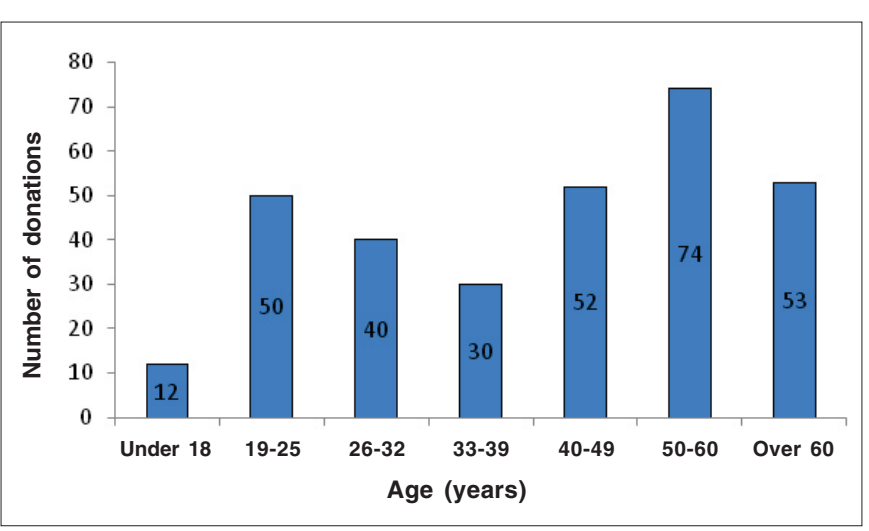

Figure 2. Number of donations by age group, Teresina/PI, 2008-2011

Statistical analysis was performed using SPSS software and was based on the chi-square test and Student's t test.A significance level of $5 \%(0.05)$ was adopted.

\section{Results}

A total of 311 cornea donors were registered at BTOCHGV over the four years of the study period (2008-2011). The number of donated corneas increased over time, from only 9 donations in 2008 to 80 in 2009, 109 in 2010, and 113 in 2011.

There was a significant predominance of male donors, with $210(67.5 \%)$ male and $101(32.5 \%)$ female donors.

Mean donor age was $43.00 \pm 16.01$ years, ranging from 10 to 80 years. Most donors $(23.8 \%)$ were aged $50-60$ years, followed those over 60 years of age, with 53 donors (17.0\%) (Figure 2).

Of a total of 622 corneas, $442(71.4 \%)$ were classified as suitable for transplantation, of which 349 (78.6\%) were assessed good or excellent, being used for optical transplant (optical corneas), and $93(20.9 \%)$ were assessed as fair or poor, being used for tectonic transplant (tectonic corneas).

Twenty-five optical corneas were subsequently discarded, of which 13 were reassessed as tectonic, 8 tested positive for hepatitis B, 3 presented tissue contamination, and 1 was in poor condition.

The mean time between death and enucleation was $3.77 \pm$ 2.18 hours. There was no statistically-significant difference between optical and tectonic corneas $(\mathrm{t}=0.028)$.

The mean time between enucleation and preservation was $6.86 \pm 6.10$ hours, and this interval was significantly lower in

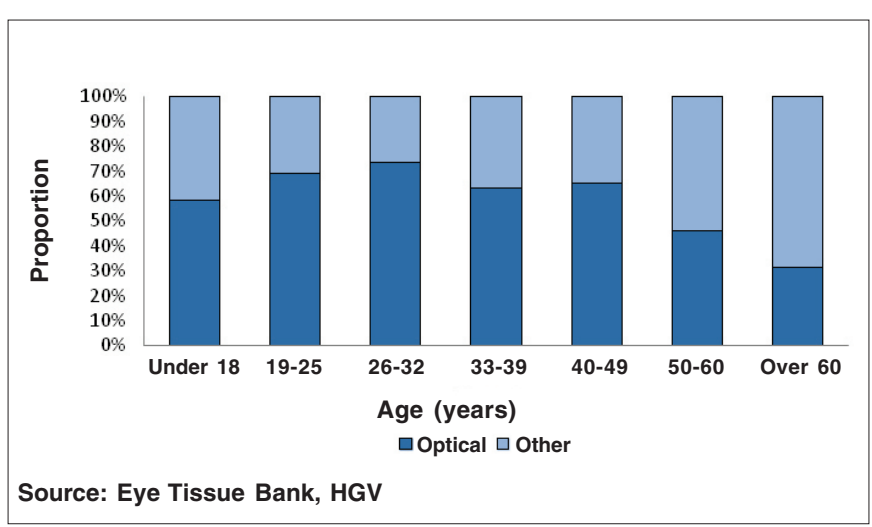

Figure 3. Proportion of corneas classified as suitable for optical transplant, Teresina/PI, 2008-2011

optical corneas $(6.49 \pm 5.69)$ than in tectonic corneas $(10.18 \pm$ 7.35) $(\mathrm{t}=1.66, \mathrm{p}=0.05)$ (Table 1$)$.

Figure 3 shows the percentage of corneas classified as optical was lower in older donors.

The causes of death of donors were grouped into 11 groups according to the International Classification of Diseases (ICD10) (Table 2). Most deaths $(141,45.34 \%)$ occurred due to external causes of morbidity and mortality (mainly violent deaths due to car accidents, suicide, and injuries with knives or firearms).Cardiovascular diseases were the second leading cause of death $(103,33.12 \%)$, followed by respiratory $(18,5.79 \%)$, gastrointestinal $(14,4.50 \%)$, and genitourinary $(14,4.50 \%)$ diseases.Neoplasms and endocrine, nutritional and metabolic diseases accounted for 7 (2.25\%) deaths each.Other causes of death included:symptoms, signs and abnormal clinical and laboratory findings not classified elsewhere (3 deaths); diseases of the blood and blood-forming organs and certain immune disorders (1 death); complications of pregnancy, childbirth and the puerperium (1 death); and injury and poisoning (1 death).The cause of death of one donor was not identified.

Donors who died from external causes had corneas of better quality than donors who died from cardiovascular diseases $\left(\div^{2}=4.64 ; \mathrm{p}=0.05\right)$. Table 3 shows that among the 349 optical corneas, $184(52.72 \%)$ were from donors who died from external causes and $104(29.80 \%)$ from cardiovascular diseases.On the other hand, of the 93 tectonic corneas, 27 (29.03\%) came from deaths due to external causes and $36(38.71 \%)$ from cardiovascular diseases.

Donors who died from external causes had corneas of better quality than donors who died from cardiovascular diseases $\left(\mathrm{X}^{2}=4.64 ; \mathrm{p}=0.05\right)$. Table 3 shows that among the 349 optical

Table 1

Time between donation and enucleation and between enucleation and preservation according to the quality of the cornea, Teresina/PI, 2008-2011

\begin{tabular}{lcc}
\hline Corneal quality & $\begin{array}{c}\text { Time between donation } \\
\text { and enucleation }(\mathbf{t}=\mathbf{0 . 0 2 8})\end{array}$ & $\begin{array}{c}\text { Time between enucleation and } \\
\text { preservation }(\mathbf{t = 1 . 6 6} \cdot \mathbf{p = 0 . 0 5})\end{array}$ \\
\hline Optical & $3.82 \pm 2.22$ & $6.49 \pm 5.69$ \\
Tectonic & $3.49 \pm 1.14$ & $10.18 \pm 7.35$ \\
Overall mean & $3.77 \pm 2.18$ & $6.86 \pm 6.10$ \\
\hline
\end{tabular}


Table 2

Causes of death of cornea donors, Teresina/PI, 2008-2011

\begin{tabular}{lr}
\hline Cause of death & $\mathbf{N}$ \\
\hline External causes of morbidity and mortality & 141 \\
Diseases of the circulatory system & 103 \\
Diseases of the respiratory system & 18 \\
Diseases of the digestive system & 14 \\
Diseases of the genitourinary system & 14 \\
Neoplasms & 7 \\
Endocrine, nutritional and metabolic diseases & 7 \\
Symptoms, signs and abnormal clinical and laboratory & 3 \\
findings, not elsewhere classified & \\
Diseases of the blood and blood-forming organs & 1 \\
and certain immune disorders & 1 \\
Pregnancy, childbirth and the puerperium & 1 \\
Injury, poisoning and certain other consequences of external causes & 1 \\
Not identified &
\end{tabular}

Table 3

Corneal quality according to the cause of death, Teresina/PI, 2008-2011

\begin{tabular}{|c|c|c|c|c|c|c|}
\hline & \multicolumn{6}{|c|}{ Corneal quality } \\
\hline & \multicolumn{2}{|c|}{ Optical } & \multicolumn{2}{|c|}{ Tectonic } & \multicolumn{2}{|c|}{ Total } \\
\hline & $\mathbf{N}$ & $\%$ & $\mathbf{N}$ & $\%$ & $\mathbf{N}$ & $\%$ \\
\hline External causes of morbidity and mortality & 184 & 52,72 & 27 & 29,03 & 211 & 47,74 \\
\hline Diseases of the circulatory system & 104 & 29,80 & 36 & 38,71 & 140 & 31,67 \\
\hline Diseases of the respiratory system & 16 & 4,58 & 8 & 8,60 & 24 & 5,43 \\
\hline Diseases of the digestive system & 9 & 2,58 & 10 & 10,75 & 19 & 4,30 \\
\hline Diseases of the genitourinary system & 14 & 4,01 & 6 & 6,45 & 20 & 4,52 \\
\hline Neoplasms & 7 & 2,01 & 1 & 1,08 & 8 & 1,81 \\
\hline Endocrine, nutritional and metabolic diseases & 9 & 2,58 & & & 10 & 2,04 \\
\hline $\begin{array}{l}\text { Symptoms, signs and abnormal clinical and laboratory } \\
\text { findings, not elsewhere classified }\end{array}$ & 2 & 0,57 & 4 & 4,30 & 6 & 1,36 \\
\hline $\begin{array}{l}\text { Diseases of the blood and blood-forming } \\
\text { organs and certain immune disorders }\end{array}$ & & & 1 & 1,08 & 1 & 0,23 \\
\hline Pregnancy, childbirth and the puerperium & 2 & 0,57 & & & 2 & 0,45 \\
\hline Not identified & 2 & 0,57 & & & 2 & 0,45 \\
\hline Total & 349 & 100,00 & 93 & 100,00 & 442 & 100,00 \\
\hline
\end{tabular}

corneas, $184(52.72 \%)$ were from donors who died from external causes and $104(29.80 \%)$ from cardiovascular diseases.On the other hand, of the 93 tectonic corneas, 27 (29.03\%) came from deaths due to external causes and 36 (38.71\%) from cardiovascular diseases.

The primary indication for corneal transplantation was bullous keratopathy on 100 recipients $(27.6 \%$ of a total of 360$)$, followed by keratoconus $(39,10.8 \%)$ and corneal perforation $(38,10.6 \%)$.A significant number of patients also required transplant due to leukoma $(29,8.1 \%)$, corneal dystrophy $(21,5.8 \%)$, primary graft failure $(21,5.8 \%)$, and rejection $(18,5.0 \%)$ (Figure 4).

\section{Discussion}

This study found a gradual increase in the number of donors over a period of four years, from only 9 donations in 2008 to 113 in 2011. These results are in agreement with studies conducted in other eye banks. For example, a study conducted at the São Paulo Hospital in 2007 found that the number of donors increased from 740 in the $1996-2000$ period to 2047 in $2001-2005^{6}$, and a study in the Sorocaba Eye Hospital found a gradual increase in the number of donated corneas, from 260 in 1984 to 2778 in $2004^{7}$. The reason for this is believed to be an increased 
Table 4

\section{Causes of death by age group, Teresina/PI, 2008-2011}

Age group $\left(X^{2}=4.66 ; p=0.05\right)$

\begin{tabular}{|c|c|c|c|c|c|c|c|c|c|c|c|c|c|c|c|c|}
\hline \multirow[t]{2}{*}{ Cause of death } & \multicolumn{2}{|c|}{ Under 18} & \multicolumn{2}{|c|}{$19-25$} & \multicolumn{2}{|c|}{$26-32$} & \multicolumn{2}{|c|}{ 33-39 } & \multicolumn{2}{|c|}{$40-49$} & \multicolumn{2}{|c|}{$50-60$} & \multicolumn{2}{|c|}{ Over 60} & \multicolumn{2}{|c|}{ Total } \\
\hline & $\mathbf{N}$ & $\%$ & $\mathbf{N}$ & $\%$ & $\mathbf{N}$ & $\%$ & $\mathbf{N}$ & $\%$ & $\mathbf{N}$ & $\%$ & $\mathbf{N}$ & $\%$ & $\mathbf{N}$ & $\%$ & $\mathbf{N}$ & $\%$ \\
\hline Neoplasms & 1 & 8.33 & & & 1 & 2.50 & & & & & 3 & 4.05 & 2 & 3.77 & 7 & 2.25 \\
\hline $\begin{array}{l}\text { Diseases of the blood and } \\
\text { blood-forming organs and }\end{array}$ & & & & & & & & & & & & & & & & \\
\hline $\begin{array}{l}\text { certain immune disorders } \\
\text { Endocrine. nutritional and }\end{array}$ & & & & & & & & & & & & & 1 & 1.89 & 1 & 0.32 \\
\hline metabolic diseases & & & & & 1 & 2.50 & & & 2 & 3.85 & 2 & 2.70 & 2 & 3.77 & 7 & 2.25 \\
\hline $\begin{array}{l}\text { Diseases of the } \\
\text { circulatory system } \\
\text { Diseases of the }\end{array}$ & 3 & 25.00 & 5 & 10.00 & 3 & 7.50 & 7 & 23.33 & 21 & 40.38 & 37 & 50.00 & 27 & 50.94 & 103 & 33.12 \\
\hline respiratory system & 1 & 8.33 & & & 1 & 2.50 & & & 1 & 1.92 & 6 & 8.11 & 9 & 16.98 & 18 & 5.79 \\
\hline $\begin{array}{l}\text { Diseases of the } \\
\text { digestive system }\end{array}$ & & & & & 3 & 7.50 & & & 3 & 5.77 & 4 & 5.41 & 4 & 7.55 & 14 & 4.50 \\
\hline $\begin{array}{l}\text { Diseases of the } \\
\text { genitourinary system }\end{array}$ & & & 1 & 2.00 & & & 1 & 3.33 & 2 & 3.85 & 8 & 10.81 & 2 & 3.77 & 14 & 4.50 \\
\hline $\begin{array}{l}\text { Pregnancy. childbirth } \\
\text { and the puerperium }\end{array}$ & & & & & & & 1 & 3.33 & & & & & & & 1 & 0.32 \\
\hline $\begin{array}{l}\text { Symptoms. signs and } \\
\text { abnormal clinical and } \\
\text { laboratory findings. }\end{array}$ & & & & & & & & & & & & & & & & \\
\hline $\begin{array}{l}\text { not elsewhere classified } \\
\text { Injury. poisoning } \\
\text { and certain other } \\
\text { consequences of }\end{array}$ & & & & & 1 & 2.50 & & & & & 1 & 1.35 & 1 & 1.89 & 3 & 0.96 \\
\hline external causes & & & & & & & & & & & 1 & 1.35 & & & 1 & 0.32 \\
\hline $\begin{array}{l}\text { External causes of } \\
\text { morbidity and mortality } \\
\text { Not identified }\end{array}$ & 7 & 58.33 & 44 & 88.00 & $30^{\circ}$ & 75.00 & 21 & 70.00 & $\begin{array}{c}22 \\
1\end{array}$ & $\begin{array}{c}42.31 \\
1.92\end{array}$ & 12 & 16.22 & 5 & 9.43 & $\begin{array}{c}141 \\
1\end{array}$ & $\begin{array}{c}45.34 \\
0.32\end{array}$ \\
\hline Total & 12 & 100.00 & 501 & 100.00 & 401 & 100.00 & 30 & 100.00 & 52 & 100.00 & 74 & 100.00 & 53 & 100.00 & 311 & 100.00 \\
\hline
\end{tabular}

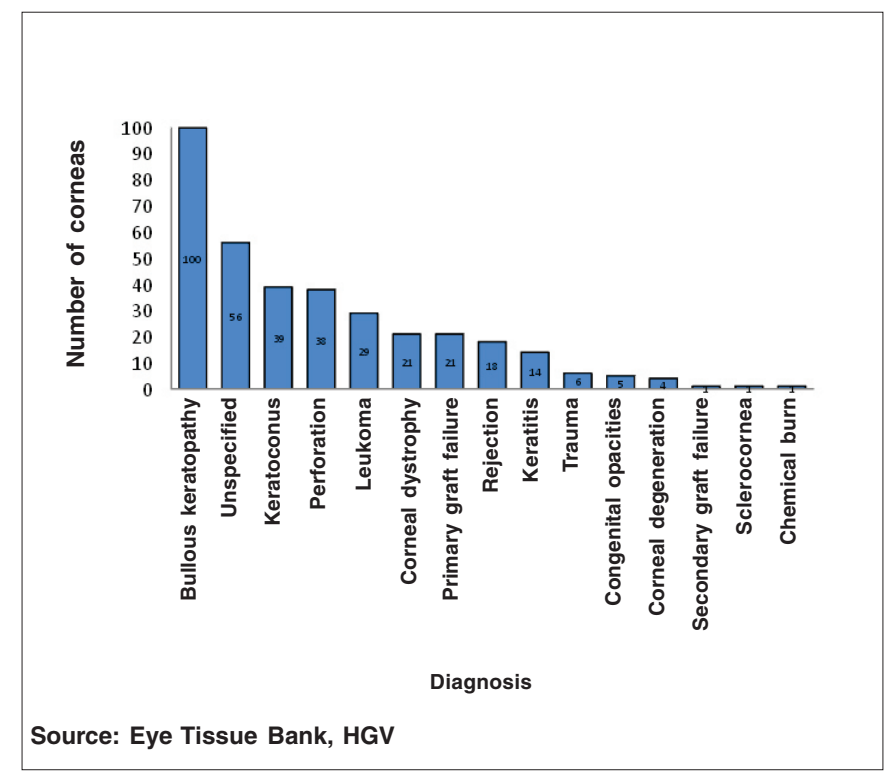

Figure 4. Indications for corneal transplantation, Teresina (PI), 20082011 awareness ofthe importance of organ donation among the population thanks to campaigns in the media, hospitals and other institutions. The study carried out in the Sorocaba Eye Hospital also found that external marketing actions had a positive impact on the number of donations in their eye bank ${ }^{7}$. Another contributing factor is the increased number of deaths from external causes over the years, especially among younger persons, due to rising levels of violence in big cities, leading to a higher number of donors aged 19-32 who die mostly from external causes (car accidents and injuries with knives or firearms).

A predominance of male donors $(67.5 \%)$ was observed, similar to studies conducted in hospitals in South-easternBrazil such as the São Paulo Hospital $(568 \%)^{6}$, the Sorocaba Eye Hospital $(55.3 \%)^{7}$, and SCMSP $(54.44 \%)^{8}$. The literature also reports a higher prevalence of male donors, which is believed to be due to the fact that men die younger from cardiovascular diseases and external causes (trauma) ${ }^{6}$. However, the proportion of male donors in BTOC-HGV was significantly higher than the average proportion reported in the literature (67.5 vs. $55 \%$, respectively $)^{7}$. This is because most corneas in this eye bank came from Teresina Emergency Hospital and the Medical-Legal Institute, where the proportion of deaths from external causes, of which men are the main victims, is particularly high. 
Mean donor age was $43.00 \pm 16.01$ years, which was significantly lower than in other studies. For example, mean donor age was $56.8 \pm 20.5$ in the São Paulo Hospital ${ }^{6}$ and $55.57 \pm 19.74$ in SCMSP. The lower life expectancy in the state of Piauí (69.8 years, according to IBGE, 2010) than in the state of São Paulo (74.8 years; IBGE, 2010)can be one of the reasons contributing to this age difference. $<0\}$

The age distribution of donors was similar to other studies in the literature, with a clear predominance of older donors ( $40.8 \%$ of donors were over 50 years of age).However, there was a predominance of donors aged 50-60 years (23.8\%) over those over 60 years $(17 \%)$, in contrast with hospitals inSoutheastern Brazil such as the São Paulo Hospital, where there is predominance donors aged $70-79$ years $(18.9 \%)$ followed by 60 69 years $(18.6 \%)^{6}$. This finding can also be explained by differences in life expectancy between regions.

We also found significant number of donors aged 19-25 years $(16.1 \%)$, as the number deaths from external causes is high in this age group.

Regarding the quality of donated corneas, 442 (71.4\%) were considered suitable for transplantation, of which $78.6 \%$ were assessed as good or excellent for optical transplant and $20.9 \%$ were recommended for tectonic transplant.However, it should be noted that some of the optical corneas $(25$, or $7.2 \%$ of optical corneas) were subsequently discarded (after preservation), most of them $(13,52 \%)$ because they were reassessed as tectonic corneas, and others $(8,32 \%)$ due to a positive serology for hepatitis B. This is in agreement with other Brazilian studies ${ }^{9,10}$ where seropositivity for hepatitis B was also a major cause of corneal discard.Of the three viral infections investigated in this study, the prevalence of HIV was the lowest, in agreement with other studies in literature ${ }^{10,11}$.

The mean time between death and enucleation was $3.77 \pm$ 2.18 hours, similar to other studies in the literature which found $3.8 \pm 2.9^{2}$ and $4.1 \pm 2.8^{12}$ hours. The time between enucleation and preservation was considerably high $(6.86 \pm 6.10$ hours $)$ compared to other studies, such as a ten-year (1996-2005) analysis of corneal donations in the Eye Bank of the São Paulo Hospital, which found $3.6 \pm 4.8$ hours, and a six-year study (2001-2006) in the same eye bank that found $6.1 \pm 5.0$ hours.

No significant difference was foundfor the time of enucleation between optical and tectonic corneas, which is consistent with some studies ${ }^{12}$, although several studies report a different finding ${ }^{13}$. It is believed that the degradation of ocular contentsafter the donor's death can alter the aqueous humour, accelerating the death of endothelial cells ${ }^{14}$. This suggests that the faster the eye is removed from the body, and the faster the cornea is removed from the eye, the lower the chance of endothelial intoxication.

However, the practical importance of this phenomenon remains unclear ${ }^{14}$. In our study,the preservation time for optical corneas was significantly lower than for tectonic corneas, similar to other studies ${ }^{12,13}$, showing the need for swift processes in eye banks, as the vitality and quality of tissues are also dependent on time.

The percentage of corneas classified as optical was significantly lower in older donors.Some studies show that corneas from younger donors tend to be more suitable for transplantation (with a higher percentage of optical transplants $)^{6,15}$. It has been observed that for every additional year of age, the chance of a cornea being classified as fair, bad or unacceptable increases by $5 \%$ regardless of other factors such as gender, enucleation time, preservation time, and origin of the cornea ${ }^{12}$. It is believed that older donorssuffer an increased loss of endothelial cells, which can compromise the outcome of transplantation.A study on the effects of donor age on corneal transplants found that even though corneas from younger donors presented less endothelial cell loss in the postoperative period, there was no difference between groups in the outcome of transplants after 5 years of follow-up ${ }^{16}$.

The main cause of death were external causes $(45.34 \%)$ followed by circulatory diseases $(33.12 \%)$, in contrast with other studies that found cardiovascular diseases as the predominant cause of donor death ${ }^{6,8,17}$.

The corneal quality of donors who died from external causes was generally better. $<0\}$

Studies show that donors who die from trauma or external causes tend to have corneas of better quality. ${ }_{<0\}}$

A study of corneal cells preserved in culture showed that corneas from donors who died due to trauma maintainedan intact metabolism, while those from donors who died from cancer or renal insufficiencyhad a reduced metabolism. However, another study found that donors who died from trauma had a greater loss of endothelial cells compared to donors with other causes of death ${ }^{12}$.

The main causes of death were external causes in younger donors and diseases of the circulatory system in older donors;a correlation was found between age and cause of death, similar to other studies ${ }^{12}$.Because of this association, it is difficult to determine whether corneal quality depends on factors associated with the cause of death itself or with donor age.

The most frequent indication for transplantation was bullous keratopathy $(27.6 \%)$, similar to studies conducted in North America ${ }^{18,19}$ and in the states of Pará and Sergipe among patients on the waiting list for transplantation ${ }^{20,21}$. Still, the percentage found in our study $(27.6 \%)$ was lower than in the aforementioned studies (31.5-40.9\%), with the exception of the study performed in the state of Pará, where the rate was similar (28.2\%). The increased number of cataract surgeries performed in the state in recent years may explain the predominance of bullous keratopathy in this study.

Some studies indicate that cataract surgery is an important cause of bullous keratopathy, and it isalso the main indication for penetrating keratoplasty ${ }^{22}$. Most of the Brazilian and European literature, however, presents keratoconus as the main cause $^{23-26}$. In our study, keratoconus was the third leading indication for transplant, affecting $10.8 \%$ of transplant recipients.

Studies in Israel and Germany showing keratoconus as the main indication for surgery attribute this finding to the demographic and genetic characteristics of the populations in these countries $^{2}$. The profile for other disorders was similar to the literature, with leukoma, perforation, and corneal dystrophy being the next leading causes for transplantation.

\section{CONCLUSION}

An increase in the number of donated corneas over the study period was observed. The main indication for corneal transplantation was bullous keratopathy.This study also found that factors such as donor age, time between enucleation and preservation, and cause of death are associated with the quality of corneas harvested by the BTOC.Further studies should be conducted to better assess eyes banks, thus helping to inform strategies aimed at increasing the number and quality of harvested corneas. 


\section{ReferenCeS}

1. Issaho DC, Tenório MB, Moreira H. [The main factors related with cornea non-donation of potential donors in a university hospital of Curitiba]. Arq Bras Oftalmol. 2009;72(4):509-14. Portuguese.

2. Barbosa AP, Almeida Junior GC, Teixeira MF, Barbosa JC. [Evaluation of penetrating keratoplasty indications in inner part of the São Paulo state]. Rev Bras Oftalmol. 2012;71(6):353-7. Portuguese.

3. Neves RC, Boteon JE, Santiago AP. [Indications for penetrating corneal graft at the São Geraldo Hospital of Minas Gerais Federal University]. Rev Bras Oftalmol. 2010;69(2):84-8. Portuguese.

4. Kara-Junior N,Mourad PC, Espíndola RF, AbilRuss HH. [Expectation and knowledge among patients with keratoplasty indication]. Rev Bras Oftalmol. 2011;70(4):230-4. Portuguese.

5. Hilgert CV,Sato ÉH. [Management performance of eye banks and its impact on those organizations results]. Rev Bras Oftalmol. 2012;71(1):28-35. Portuguese.

6. Adán CB, Diniz AR, Perlatto D, Hirai FE, Sato EH. [Ten years of corneal donation to the Hospital São Paulo Eye Bank: characteristics of cornea donors from 1996 to 2005]. Arq Bras Oftalmol. 2008;71(2):176-81. Portuguese.

7. Farias RJ, Sousa LB. [Marketing role of corneal graft tissue donation to an eye bank and donors' socioeconomic profile]. Arq Bras Oftalmol. 2008;71(1):28-33. Portuguese.

8. Sano RY, Sano FT, Dantas MC,Lui AC, Sano ME, Lui Neto A. [Analysis of the transplanted corneas at Santa Casa de São Paulo Eye Bank]. Arq Bras Oftalmol. 2010;73(3):254-8. Portuguese.

9. Galluzi CG, Pacini KM, Adán CB, Sato EH. [Discarding causes of cornea collected by eye bank of São Paulo hospital in two years]. Rev Bras Oftalmol. 2010;69(1):18-22. Portuguese.

10. Viegas MT, Pessanha LC, Sato EH, Hirai FE, Adán CB. [Discarded corneas due to positive donor's serologic test in the Hospital São Paulo Eye Bank: a two-year study]. Arq Bras Oftalmol. 2009;72(1):180-4. Portuguese.

11. Armstrong SA, Gangam N, Chipman ML, Rootman DS. The prevalence of positive hepatitis B, hepatitis C, and HIV serology in cornea donors prescreened by medical and social history in Ontario, Canada. Cornea. 1997;16(5):512-6.

12. Hirai FE, Adán CB, Sato EH. [Factors associated with quality of donated corneas in the Hospital São Paulo Eye Bank]. Arq Bras Oftalmol. 2009;72(1):57-61.Portuguese.

13. Probst LE, Halfaker BA, Holland EJ. Quality of corneal donor tissue in the greater-than-75-year age group. Cornea. 1997;16(5):507-11.

14. Marcomini LA, Sobral RM, Seixas GO, Faria e Sousa SJ. [Corneal selection for transplants]. Rev Bras Oftalmol. 2011;70(6):430-6. Portuguese.

15. Farge EJ, Cox WG, Khan MM. An eye banking program for selecting donor corneas for surgical distribution. Cornea. 1995;14(6):578-82.
16. Cornea Donor Study Investigator Group, gal RL, Dontchev M, Beck RW, Mannis MJ, Holland EJ, Kollman C, Dunn SP, Heck EL, Lass JH, Montoya MM, Schultze RL, Stulting RD, Sugar A, Sugar J, Tennant B, Verdier DD. The effect of donor age on corneal transplantation outcome results of the cornea donor study. Ophthalmology.2008;115(4):620-626.e6.

17. Shiratori CN, Hirai FE, Sato EH. [Characteristics of corneal donors in the Cascavel Eye Bank: impact of the anti-HBc test for hepatitis B]. Arq Bras Oftalmol. 2011;74(1):17-20. Portuguese.

18. Cosar CB, Sridhar MS, Cohen EJ,Held EL, Alvim Pde T, Rapuano CJ, et al. Indications for penetrating keratoplasty and associated procedures, 1996-2000. Cornea. 2002;21(2):148-51.

19. Dobbins KR, Price FW Jr, Whitson WE. Trends in the indications for penetrating keratoplasty in the midwestern United States. Cornea. 2000;19(6):813-6.

20. Araújo AA, Melo GB, Silva RL, Araújo Neta VM. [Epidemiological profile of the patients on the waiting list for cornea transplantation in the State of Sergipe, Brazil]. Arq Bras Oftalmol. 2004;67(4):613-6. Portuguese.

21. Almeida Sobrinho EF, Negrão BC, Almeida, HG. [Epidemiological profile of patients waiting for penetrating keratoplasty in state of Pará, Brazil]. Rev Bras Oftalmol. 2011;70(6):384-90. Portuguese.

22. Santhiago MR, Monica LA, Kara-Junior N, Gomes BA, Bertino PM, Mazurek Mg, et al. [Profile of patient with aphakic/pseudopfakic bullous keratopaty attended at public hospital]. Rev Bras Oftalmol. 2009;68(4):201-5. Portuguese.

23. Calix Neto MJ, Giustina ED, Ramos GZ, Peccini RF, Sobrinho M, Souza LB. [Major indications for corneal penetrating keratoplasty at a reference service in São Paulo state (Sorocaba - SP, Brazil)]. Arq Bras Oftalmol. 2006;69(5):661-4. Portuguese.

24. Cattani S, Kwitko S, Kroeff MA, Marinho D, Rymer S, Bocaccio FL. [Indications for corneal graft surgery at the Hospital de Clínicas of Porto Alegre]. Arq Bras Oftalmol. 2002;65(1):95-8. Portuguese.

25. Legeais JM, Parc C, d'Hermies F, Pouliquen Y, Renard G. Nineteen years of penetrating keratoplasty in the Hotel-Dieu Hospital in Paris. Cornea. 2001;20(6):603-6.

26. Zeschau A, Balestrin IG, Stock RA, Bonamigo EL. [Indications of keratoplasty: a retrospective study in a University Hospital. Rev Bras Oftalmol. 2013;72(5):316-20. Portuguese.

\section{Corresponding author:}

Namir Clementino Santos

Rua Professor Clemente Fortes, 2390

São Cristóvão, Teresina/PI, Brazil.

namirsantos@ig.com.br 